\title{
Interactions between Thyroid and Growth Factors during Development
}

\author{
Ahmed R.G* \\ Division of Anatomy and Embryology, Zoology Department, Faculty of Science, Beni-Suef University, Beni- \\ Suef, Egypt
}

*Corresponding Author: Ahmed R.G, Division of Anatomy and Embryology, Zoology Department, Faculty of Science, Beni-Suef University, Beni-Suef, Egypt, Email: ahmedragab08@gmail.com

\section{COMMENTARY}

Thyroid hormones (THs) show acrucialactions during the normal development (El-bakry et al., 2010; Ahmed, 2011, 2012a,b, 2013, 2014, 2015a-c, 2016a-d, 2017a-u, 2018; Ahmed et al., 2008, 2010, 2012, 2013a,b, 2014, 2015a,b, 2018; Ahmed and Ahmed, 2012; Ahmed and Incerpi, 2013; Van Hercket al., 2013; Ahmed and El-Gareib, 2014,Incerpi et al., 2014; Candelotti et al., 2015; De Vito et al., 2015; ElGhareeb et al., 2016; Ahmed and El-Gareib, 2017), particularly growth factors such as insulin-growth factor (IGF-1), fibroblast-growth factor (FGF), transforming growth factor- $\alpha$ (TGF- $\alpha$ ), and epidermal-growth factor (EGF) (Candelotti et al., 2015). Indeed, integrin $\alpha v \beta 3$ is a co-receptor for these growth factors (Saegusa et al., 2009; Ieguchi et al., 2010). Otherwise, these growth factors may stimulate the release of THs, and generally the development (Ahmed et al., 2015a; Candelotti et al., 2015; Ahmed, 2016d). In addition, vascular endothelial growth factor (VEGF), FGF, and basic fibroblast growth factor (bFGF) might prompt THs-induced angiogenesis in the cardiac tissue (Wang et al., 2004; Zheng et al., 2004). Also, angiogenesis depends on integrin $\alpha v \beta 3$ of both endothelial and vascular smooth muscle cells (Bergh et al., 2005; Candelotti et al., 2015). Thus, angiogenesis seems to be a good example of the complex interactions between THs and growth factors.

On the other hand, it has been confirmed by the group of Takada and Takada that an integrinbinding defective-FGF1 mutant (R50E) profoundly decreased the ability of the growth factor to induce cell proliferation and migration, even though R50E did provide increase to FGFR1 phosphorylation and downstream protein kinase B (AKT) and activated protein kinase (ERK1/2) (Ieguchi et al., 2010). In addition, Mori et al. (2008) suggested that there is a direct crosstalk between the integrin $\alpha v \beta 3$ and FGF. Also, Saegusa et al. (2009) and Ieguchi et al. (2010) concluded that the binding of integrin $\alpha v \beta 3$ plays an important role in the signaling of growth factors, particularly EGF and IGF-1. Other members of the EGF family are neuregulins (NRGs) that are binding to integrins. This binding is vital for the effective growth factor signaling (Ieguchi et al., 2010). In addition, Ieguchi and co-researchers in a great experiment found that the direct associations between NRG1 and integrin $\alpha v \beta 3$ were significant for the activation of the ErbB receptor-tyrosine kinases resulting in downstream signaling activation of Akt and ERK1/2 (Ieguchi et al., 2010). Thus, different growth factors may compete for interaction with the same integrin (Candelotti et al., 2015). Additionally, Shih et al. (2004) reported that thyroid (T4) has the ability to increase EGF and TGF- $\alpha$-induced MAPK activation in HeLa cells that lacked thyroid receptors (TRs). However, NRGs are implicated in several diseases such as schizophrenia, cancer and cardiovascular disorders (Candelotti et al., 2015). Collectively, my group (Candelotti et al., 2015) reported that understanding the role of THs in this crosstalk may facilitate the development of new tools for therapeutic intervention, and in this context the nanotetrac formulation appears to be very promising. Additional studies are wanted to identify the crosstalk between THs and growth factors to prove the efficacy of new pharmacological drugs. 


\section{REFERENCES}

[1] Ahmed, R.G., El-Gareib, A.W., Incerpi, S., 2014. Lactating PTU exposure: II- Alters thyroid-axis and prooxidant-antioxidant balance in neonatal cerebellum. Int. Res. J. of Natural Sciences 2(1), 1-20.

[2] Ahmed, O.M., Abd El-Tawab, S.M., Ahmed, R.G., 2010. Effects of experimentally induced maternal hypothyroidism and hyperthyroidism on the development of rat offspring: I- The development of the thyroid hormonesneurotransmitters and adenosinergic system interactions. Int. J. Dev. Neurosci. 28, 437-454.

[3] Ahmed, O.M., Ahmed, R.G., 2012. Hypothyroidism. In A New Look At Hypothyroidism. Dr. D. Springer (Ed.), ISBN:978-953-51-0020-1), In Tech Open Access Publisher, Chapter 1, pp. 1-20.

[4] Ahmed, O.M., Ahmed, R.G., El-Gareib, A.W., El-Bakry, A.M., Abd El-Tawaba, S.M., 2012. Effects of experimentally induced maternal hypothyroidism and hyperthyroidism on the development of rat offspring: II-The developmental pattern of neurons in relation to oxidative stress and antioxidant defense system. Int. J. Dev. Neurosci. 30, 517-537.

[5] Ahmed, O.M., El-Gareib, A.W., El-bakry, A.M., Abd El-Tawab, S.M., Ahmed, R.G., 2008. Thyroid hormones states and brain development interactions. Int. J. Dev. Neurosci. 26(2), 147-209. Review.

[6] Ahmed, R.G., 2011. Perinatal 2, 3, 7, 8tetrachlorodibenzo-p-dioxin exposure alters developmental neuroendocrine system. Food Chem. Toxicology, 49, 1276-1284.

[7] Ahmed, R.G., 2012a. Maternal-newborn thyroid dysfunction.In the Developmental Neuroendocrinology, pp. 1-369. Ed R.G. Ahmed. Germany: LAP LAMBERT Academic Publishing GmbH \& Co KG.

[8] Ahmed, R.G., 2012b. Maternal-fetal thyroid interactions, Thyroid Hormone, Dr. N.K. Agrawal (Ed.), ISBN: 978-953-51-0678-4, In Tech Open Access Publisher, Chapter 5, pp. 125-156.

[9] Ahmed, R.G., 2013. Early weaning PCB 95 exposure alters the neonatal endocrine system: thyroid adipokine dysfunction. J. Endocrinol. 219 (3), 205-215.

[10] Ahmed, R.G., 2014. Editorial: Do PCBs modify the thyroid-adipokine axis during development? Annals Thyroid Res. 1(1), 11-12.

[11] Ahmed, R.G., 2015a. Chapter 1: Hypothyroidism and brain development. In advances in hypothyroidism treatment. Avid Science Borsigstr.9, 10115 Berlin, Berlin, Germany. Avid Science Publications level 6, Melange Towers, Wing a, Hitec City, Hyderabad, Telangana, India. pp. 1-40.
[12] Ahmed, R.G., 2015b. Hypothyroidism and brain developmental players. Thyroid Research J. 8(2), 1-12.

[13] Ahmed, R.G., 2015c. Editorials and Commentary: Maternofetal thyroid action and brain development. J. of Advances in Biology; 7(1), 1207-1213.

[14] Ahmed, R.G., 2015d. Developmental adipokines and maternal obesity interactions. J. of Advances in Biology; 7(1), 1189-1206.

[15] Ahmed, R.G., 2016a. Gestational dexamethasone alters fetal neuroendocrine axis. Toxicology Letters, 258, 46-54.

[16] Ahmed, R.G., 2016b. Neonatal polychlorinated biphenyls-induced endocrine dysfunction. Ann. Thyroid. Res. 2 (1), 34-35.

[17] Ahmed, R.G., 2016c. Maternal iodine deficiency and brain disorders.Endocrinol.Metab.Syndr.5, 223.http://dx.doi.org/10.4172/2161-1017. 1000 223.

[18] Ahmed, R.G., 2016d. Maternal bisphenol A alters fetal endocrine system: Thyroid adipokine dysfunction. Food Chem. Toxicology, 95, 168-174.

[19] Ahmed, R.G.,2017a. Developmental thyroid diseases and GABAergic dysfunction. EC Neurology 8.1, 02-04.

[20] Ahmed, R.G., 2017b. Hyperthyroidism and developmental dysfunction.Arch Med. 9, 4.

[21] Ahmed, R.G.,2017c. Anti-thyroid drugs may be at higher risk for perinatal thyroid disease. EC Pharmacology and Toxicology 4.4, 140-142.

[22] Ahmed, R.G., 2017d. Perinatal hypothyroidism and cytoskeleton dysfunction. Endocrinol Metab Syndr 6, 271.doi:10.4172/21611017.1000271

[23] Ahmed, R.G.,2017e. Developmental thyroid diseases and monoaminergic dysfunction. Advances in Applied Science Research 8(3), 01-10.

[24] Ahmed, R.G.,2017f. Hypothyroidism and brain development.J. Anim Res Nutr.2(2), 13.

[25] Ahmed, R.G.,2017g. Antiepileptic drugs and developmental neuroendocrine dysfunction: Every why has A Wherefore. Arch Med 9(6), 2.

[26] Ahmed, R.G.,2017h. Gestational prooxidantantioxidant imbalance may be at higher risk for postpartum thyroid disease. Endocrinol Metab Syndr 6, 279. doi:10.4172/2161-1017.1000279.

[27] Ahmed, R.G.,2017i. Synergistic actions of thyroid-adipokines axis during development. Endocrinol Metab Syndr 6, 280.doi: 10.4172/ 2161-1017.1000280.

[28] Ahmed, R.G.,2017j. Thyroid-insulin dysfunction during development. International Journal of Research Studies in Zoology 3(4), 73-75. DOI: http://dx.doi.org/10.20431/2454941X.0304010. 
[29] Ahmed, R.G., 2017k. Developmental thyroid diseases and cholinergic imbalance. International Journal of Research Studies in Zoology 3(4), 70-72. DOI: http://dx.doi.org/ 10.20431/2454-941X.0304009.

[30] Ahmed, R.G.,20171. Thyroid diseases and developmental adenosinergic imbalance.Int $\mathbf{J}$ ClinEndocrinol 1(2), 053-055.

[31] Ahmed, R.G.,2017m. Maternal anticancer drugs and fetal neuroendocrine dysfunction in experimental animals. Endocrinol Metab Syndr 6, 281.doi:10.4172/2161-1017.1000281.

[32] Ahmed, R.G.,2017n. Letter: Gestational dexamethasone may be at higher risk for thyroid disease developing peripartum. Open Journal Of Biomedical \& Life Sciences (Ojbili) 3(2), 01-06.

[33] Ahmed, R.G.,2017o.Deiodinases and developmental hypothyroidism. EC Nutrition 11.5, 183-185.

[34] Ahmed, R.G.,2017p.Maternofetal thyroid hormones and risk of diabetes. Int. J. of Res. Studies in Medical and Health Sciences 2(10), 18-21.

[35] Ahmed, R.G.,2017r.Association between hypothyroidism and renal dysfunctions. International Journal of Research Studies in Medical and Health Sciences 2(11), 1-4.

[36] Ahmed, R.G.,2017s. Maternal hypothyroidism and lung dysfunction. International Journal of Research Studies in Medical and Health Sciences 2(11), 8-11.

[37] Ahmed, R.G.,2017t. Endocrine disruptors; possible mechanisms for inducing developmental disorders.International journal of basic science in medicine (IJBSM) 2(4), xxXX. (in press)

[38] Ahmed, R.G.,2017u.Maternal thyroid hormones trajectories and neonatal behavioral disorders. ARC Journal of Diabetes and Endocrinology 3(2), 18-21.

[39] Ahmed, R.G.,2018. Maternal hypothyroidism and neonatal testicular dysfunction. International Journal of Research Studies in Medical and Health Sciences 3(1), 8-12.

[40] Ahmed, R.G., Abdel-Latif, M., Ahmed F., 2015b.Protective effects of GM-CSF in experimental neonatal hypothyroidism. International Immunopharmacology 29, 538543.

[41] Ahmed, R.G., Abdel-Latif, M., Mahdi, E., ElNesr, K., 2015a. Immune stimulation improves endocrine and neural fetal outcomes in a model of maternofetal thyrotoxicosis. Int. Immunopharmacol. 29, 714-721.

[42] Ahmed, R.G., Davis, P.J., Davis, F.B., De Vito, P., Farias, R.N., Luly, P., Pedersen, J.Z., Incerpi, S., 2013b. Nongenomic actions of

ARC Journal of Diabetes and Endocrinology thyroid hormones: from basic research to clinical applications. An update. Immunology, Endocrine \& Metabolic Agents in Medicinal Chemistry, 13(1), 46-59.

[43] Ahmed, R.G.,El-Gareib, A.W., Shaker, H.M., 2018. Gestational 3,3',4,4',5pentachlorobiphenyl (PCB 126) exposure disrupts fetoplacental unit: Fetal thyroidcytokines dysfunction. Life Sciences 192, 213220.

[44] Ahmed, R.G., El-Gareib, A.W. 2014.Lactating PTU exposure: I- Alters thyroid-neural axis in neonatal cerebellum. Eur. J. of Biol. and Medical Sci. Res. 2(1), 1-16.

[45] Ahmed, R.G., El-Gareib, A.W., 2017.Maternal carbamazepine alters fetal neuroendocrinecytokines axis. Toxicology 382, 59-66.

[46] Ahmed, R.G., Incerpi, S., 2013. Gestational doxorubicin alters fetal thyroid-brain axis. Int. J. Devl. Neuroscience 31, 96-104.

[47] Ahmed, R.G., Incerpi, S., Ahmed, F., Gaber, A., 2013a. The developmental and physiological interactions between free radicals and antioxidant: Effect of environmental pollutants. J. of Natural Sci. Res. 3(13), 74-110.

[48] Bergh, J.J., Lin, H.-Y., Lansing, L., Mohamed, S.N., Davis, F.B., Mousa, S., Davis, P.J., 2005. Integrin $\alpha v \beta 3$ contains a cell surface receptor site for thyroid hormone that is linked to activation of mitogen activated protein kinase and induction of angiogenesis. Endocrinol. 146, 2864-2871.

[49] Candelotti, E., De Vito, P., Ahmed, R.G., Luly, P., Davis, P.J., Pedersen, J.Z., Lin, H-Y., Incerpi, I., 2015. Thyroid hormones crosstalk with growth factors: Old facts and new hypotheses. Immun., Endoc.\&Metab. Agents in Med. Chem., 15, 71-85.

[50] De Vito, P., Candelotti, E., Ahmed, R.G., Luly, P., Davis, P.J., Incerpi, S., Pedersen, J.Z., 2015.Role of thyroid hormones in insulin resistance and diabetes.Immun., Endoc.\&Metab. Agents in Med. Chem., 15, 8693.

[51] El-bakry, A.M., El-Ghareeb, A.W.,Ahmed, R.G., 2010.Comparative study of the effects of experimentally-induced hypothyroidism and hyperthyroidism in some brain regions in albino rats.Int. J. Dev. Neurosci. 28, 371-389.

[52] El-Ghareeb, A.A., El-Bakry, A.M., Ahmed, R.G., Gaber, A., 2016.Effects of zinc supplementation in neonatal hypothyroidism and cerebellar distortion induced by maternal carbimazole. Asian Journal of Applied Sciences 4(04), 1030-1040.

[53] Ieguchi, K.I., Fujita, M., Ma, Z., Davari, P., Taniguchi, Y., Sekiguchi, K., Wang, B., Takada, Y.K, Takada, Y., 2010. Direct binding of the EGF-like domain of neuregulin-1 to integrins $\alpha v \beta 3$ and $\alpha 6 \beta 4$ is involved in 
neuregulin-1/ErbB signaling. J. Biol. Chem. 285, 31388-31398.

[54] Incerpi, S., Hsieh, M-T., Lin, H-Y., Cheng, GY., De Vito, P., Fiore, A.M., Ahmed, R.G., Salvia, R., Candelotti, E., Leone, S., Luly, P., Pedersen, J.Z., Davis, F.B., Davis, P.J., 2014. Thyroid hormone inhibition in L6 myoblasts of IGF-I-mediated glucose uptake and proliferation: new roles for integrin $\alpha v \beta 3$. Am. J. Physiol. Cell Physiol. 307, C150-C161.

[55] Mori, S.I., Wu, C.Y., Yamaji, S.,Saegusa, J., Shi, B., Ma, Z., Kuwabara, Y., Lam, K.S., Isseroff, R.R., Takada, Y.K., Takada, Y., 2008. Direct binding of integrin $\alpha v \beta 3$ to FGF1 plays a role in FGF1 signaling.J. Biol. Chem. 283, 18066-18075.

[56] Saegusa, J.I., Yamaji, S., Ieguchi, K., Wu, C.Y., Lam, K.S., Liu, F.T., Takada, Y.K., Takada, Y., 2009. The direct binding of insulinlike growth factor-1 (IGF-1) to integrin $\alpha \mathrm{v} \beta 3$ is involved in IGF-1 signaling. J. Biol. Chem. 284, 24106-24114.

[57] Shih, A., Zhang, S., Cao, H.J., Tang, H.Y., Davis, F.B., Davis, P.J., Lin, H.Y., 2004.
Disparate effects of thyroid hormone on actions of epidermal growth factor and transforming growth factor- $\alpha$ are mediated by $3^{\prime}, 5^{\prime}$-cyclic adenosine 5'-monophosphate-dependent protein kinase II. Endocrinology, 145, 1708-1717.

[58] Van Herck, S.L.J., Geysens, S., Bald, E., Chwatko, G., Delezie, E., Dianati, E., Ahmed, R.G., Darras, V.M., 2013.Maternal transfer of methimazole and effects on thyroid hormone availability in embryonic tissues.Endocrinol. 218, 105-115.

[59] Wang, X., Zheng, W., Christensen, L.P., Tomanek, R.J., 2004. DITPA stimulates bFGF, VEGF, angiopoietin, and Tie-2 and facilitates coronary arteriolar growth. Am. J. Physiol. Heart Circ. Physiol. 286, 1994-2000.

[60] Zheng, W.I., Weiss, R.M., Wang, X., Zhou, R., Arlen, A.M., Lei, L., Lazartigues, E., Tomanek, R.J., 2004. DITPA stimulates arteriolar growth and modifies myocardial postinfarction remodeling. Am. J. Physiol. Heart Circ. Physiol. 286, 1994-2000.

Citation: Ahmed R.G. Interactions between Thyroid and Growth Factors during Development. ARC Journal of Diabetes and Endocrinology. 2018; 4(1):1-4. doi:dx.doi.org/10.20431/2455-5983.0401001.

Copyright: (C) 2018 Authors. This is an open-access article distributed under the terms of the Creative Commons Attribution License, which permits unrestricted use, distribution, and reproduction in any medium, provided the original author and source are credited. 